\title{
Short Communication: Quality of ewe and goat meat cured product mantas. An approach to provide value added to culled animals
}

\author{
António F. Oliveira ${ }^{1}$, Sandra Rodrigues ${ }^{2,3}$, Ana Leite ${ }^{1}$, Kátia Paulos ${ }^{1}$, \\ Etelvina Pereira ${ }^{3}$, and Alfredo Teixeira ${ }^{1,3,4}$ \\ ${ }^{1}$ Veterinary and Animal Research Centre (CECAV) Universidade Trás-os-Montes e Alto Douro; ${ }^{2}$ Mountain \\ Research Centre (CIMO); and ${ }^{3}$ Escola Superior Agrária/Instituto Politécnico de Bragança, Campus \\ Sta Apolónia Apt 1172 5301-855 Bragança, Portugal. Received 17 December 2013, \\ accepted 29 April 2014. Published on the web 20 May 2014.
}

\begin{abstract}
Oliveira, A. F., Rodrigues, S., Leite, A., Paulos, K., Pereira, E. and Teixeira, A. 2014. Short Communication: Quality of ewe and goat meat cured product mantas. An approach to provide value added to culled animals. Can. J. Anim. Sci. 94: 459-462. The effect of species on quality of a cured meat product (mantas) was analyzed in eight culled ewes and eight culled goats. Carcasses were aged at $4{ }^{\circ} \mathrm{C}$ for $4 \mathrm{~d}$, deboned, salted for $96 \mathrm{~h}$ and dried for $48 \mathrm{~h}$. Samples (in triplicate) from the longissimus dorsi (LD) were analyzed for $\mathrm{pH}$ and water activity $\left(\mathrm{a}_{\mathrm{w}}\right)$. Samples of cured LD were subjected to chemical analyses. It was possible to conclude that cured goat meat had higher moisture content $(P<0.001)$ than cured ewe meat, 44 and $51 \%$, respectively. Directly related to the moisture content, a higher total, saturated, mono- and polyunsaturated fat content $(P<0.001)$ was found in ewes. The others chemical determinations did not present differences $(P>0.05)$ for the species effect.
\end{abstract}

Key words: Goat, ewe, meat, processed product

\begin{abstract}
Oliveira, A. F., Rodrigues, S., Leite, A., Paulos, K., Pereira, E. et Teixeira, A. 2014. Communication Brève: La qualité du mantas, un produit de charcuterie-salaison de brebis et de chèvre. Une approche pour offrir une valeur ajoutée aux animaux de réforme. Can. J. Anim. Sci. 94: 459-462. L'effet de l'espèce sur la qualité d'un produit de charcuterie-salaison (mantas) a été analysé chez huit brebis de réforme et 8 chèvres de réforme. Les carcasses ont été vieillies à $4^{\circ} \mathrm{C}$ pendant 4 jours, désossées, salées pendant $96 \mathrm{~h}$, puis séchées pendant $48 \mathrm{~h}$. Les échantillons (en triplicats) du muscle longissimus dorsi (LD) ont été analysés pour le $\mathrm{pH}$ et l'activité de l'eau $\left(\mathrm{a}_{\mathrm{w}}-\right.$ « water activity $)$. L'analyse chimique a été effectuée dans des échantillons de LD saumuré. Il a été possible de conclure que la viande de chèvre saumurée avait une teneur plus élevée en eau $(P<0,001)$ que la viande de brebis $(44 \%$ et $51 \%$ d'eau respectivement). Directement liée à la teneur en eau rapportée, une teneur plus élevée $(P<0,001)$ en matières grasses totales, saturées, mono-insaturées et polyinsaturées a été observée chez les brebis. Les autres analyses chimiques ne présentaient pas de différences $(P>0,05)$ entre les espèces.
\end{abstract}

Mots clés: Chèvre, brebis, viande, produits transformés

In Portugal, as well as in other Mediterranean countries, quality sheep and goat products are available. However, carcasses from culled animals of breeds from certified quality label products have a lower price and poor consumer acceptability. Meat from such animals is more suitable to process as dried, cured or smoked products (Webb et al. 2005). In several countries, culled animals are slaughtered and their meat is processed, for example, the Spanish cecina de castron (Hierro et al. 2004), the Italian violin di capra (Fratianni et al. 2008) or the Brazilian charqui and manta (Madruga and Bresan 2011).

The objective of this study was to recover value from aged sheep and goats from flocks in the northeast of Portugal by creating a distinct product. At the same time, the effect of species (sheep vs. goat) on the quality of physicochemical characteristics of a processed meat product, manta, was evaluated.

${ }^{4}$ Corresponding author (e-mail: teixeira@ipb.pt).
Carcasses were acquired directly from the Serrana and Bragançana National Associations of Breed Producers (Mirandela and Bragança, Portugal); experiments were not conducted on live animals. The research project was approved by the Agro Program of the INIAP from Portuguese Agricultural Ministry. The authors certify that animals were cared for under guidelines comparable to those laid down by the Canadian Council on Animal Care.

\section{Animal Sampling, Carcass Manipulation and Meat Processing}

Sixteen culled animals, eight Bragançana ewes and eight Serrana goats, between 8 and $12 \mathrm{yr}$ old, with an average of $45 \pm 5 \mathrm{~kg}$ liveweight, were randomly selected from

\footnotetext{
Abbreviations: IMF, intramuscular fat; LD, longissimus dorsi; MUFA, monounsaturated fatty acid; PUFA, polyunsaturated fatty acid; SFA, saturated fatty acid; TBARS, 2-thiobarbituric acid reactive substances
} 
several flocks by two breeder associations. All animals were raised under the same production system, based on daily natural grassland and ad libitum wheat or rye straw. Animals were slaughtered in the official slaughterhouse of Bragança (Trás-os-Montes, northeast Portugal). The average carcass weight was $20 \pm 1.9 \mathrm{~kg}$. After ageing, carcasses were divided into quarters by a straight cut from the point close to the lower edge of the backbone at the 13th rib, and then deboned separating only the long bones and vertebral column, retaining the ribs in the anterior quarter and preventing muscles from being separated, which resembled a blanket (manta) of meat. The mantas (eight per species) were then salted and placed on top of each other, in piles, separated by $5 \mathrm{~cm}$ of coarse marine salt, for $96 \mathrm{~h}$ in a cooler with a constant temperature of $4{ }^{\circ} \mathrm{C}$ and relative humidity of $75 \%$. Every $12 \mathrm{~h}$ the piles were rearranged, moving down the upper mantas and redistributing the pressure. Mantas were then washed, removing excess salt, and air-dried in a room with a temperature of $8-10^{\circ} \mathrm{C}$ and relative humidity of $60-70 \%$ for $48 \mathrm{~h}$. Finally, samples were taken from the LD muscle for physicochemical analysis and mantas were vacuum packed and refrigerated.

\section{pH and $\mathrm{a}_{\mathrm{w}}$ Measurements}

One hour post mortem $\mathrm{pH}$ values were recorded from the LD muscle between the 12th and 13th ribs of the left side of carcass. Carcasses were then cooled at $4 \pm 1^{\circ} \mathrm{C}$ for an ageing period of $4 \mathrm{~d}$. Twenty-four hours after slaughter, $\mathrm{pH}$ was measured again. Water activity $\left(a_{w}\right)$ in raw fresh meat and at the end of the fabrication process of mantas was measured with a probe measuring over the range of $0-1$, with room temperature control.

\section{Chemical Composition Analysis}

Meat samples were previously minced. Moisture and ash contents were determined according to Portuguese Standards (NP) [NP 1614 (2002) and NP 1615 (2002) respectively]. Crude protein content was measured according to NP 1612 (1979). Lipid oxidation was monitored by measuring 2-thiobarbituric acid reactive substances (TBARS) at the end of the drying process. Total fat was determined by gas chromatography according to AOAC standards [Association of Official Analytical Chemists (AOAC) 1997] with BÜCHI instruments. All analyses were performed in triplicate.

\section{Fatty Acid Quantification}

Fatty acid determination was preformed using the BÜCHI Fat Determination System (AOAC International), which consists of the Extraction Unit B-815 for simultaneous extraction/saponification of the fatty acids, and the Fat Determination B-820, which determines the fat content based on the isolated fatty acids by means of gas chromatography (Teixeira and Rodrigues 2013).

\section{Statistical Analysis}

A one-way analysis of variance (ANOVA) was carried out to analyze the species effect. Statistical analysis was performed using the statistical package JMP Pro 10 (2012 SAS (C) Institute, Inc.)

Means $( \pm \mathrm{SD})$ of $\mathrm{pH}$ and $\mathrm{a}_{\mathrm{w}}$ values are presented in Table 1. No significant differences $(P>0.05)$ between species were found except for $\mathrm{pH}$ value assessed at $24 \mathrm{~h}$ after slaughter, which was significantly $(P<0.01)$ higher in goat than ewe mantas. Both $\mathrm{pH}$ and $\mathrm{a}_{\mathrm{w}}$ values dropped from 1 to $24 \mathrm{~h}$ after slaughter in accordance with the results found and described previously by Teixeira et al. $(2010,2011) . \mathrm{pH}$ and $\mathrm{a}_{\mathrm{w}}$ are also in agreement with the values found by Rubio et al. (2007) in a similar product, beef cecina $\left(\mathrm{pH}=5.85-6.03\right.$ and $\left.\mathrm{a}_{\mathrm{w}}=0.878-0.923\right)$.

No significant differences $(P>0.05)$ were found for TBARS, protein and ash contents between ewe and goat mantas, but the latter showed a significantly higher moisture content of $6.5 \%(P<0.001)$ (Table 1). Both mantas had high protein content $(23.9 \%)$, as observed for similar products such as jerked beef, with $\sim 25 \%$ protein, according to Cristian (2006). However, a recent study by Costa et al. (2011) has found lower protein content than in the present study in salted lamb and goat meat. The relatively low ash content of the meat is in agreement with the results of Madruga et al. (2008), and the majority of the minerals found in this kind of meat are in the form of chlorides directly associated with the addition of salt during the manta manufacture. TBARS values, a measure of lipid oxidation recorded, were lower than the values found in salted sheep meat by Sobrinho et al. (2004). These results suggest that we can develop a similar product, but with better fat quality, namely in poluunsaturated fatty acid (PUFA) values, that are so important in several diets.

The goat manta had a higher moisture content $(P<0.001)$ than the sheep manta, which was expected and was related to fat content, since sheep meat had higher intramuscular fat (IMF) content than goat meat, as was also found by Babiker et al. (2003) and Sobrinho et al. (2004) working with salted sheep and goat meats, respectively.

\begin{tabular}{|c|c|c|c|}
\hline$N=48$ & Ewe & Goat & Significance \\
\hline $\mathrm{pH}_{1 \mathrm{~h}}$ & $6.37 \pm 0.11$ & $6.43 \pm 0.15$ & NS \\
\hline $\mathrm{pH}_{24 \mathrm{~h}}$ & $5.75 \pm 0.03$ & $5.88 \pm 0.04$ & $* *$ \\
\hline $\mathrm{a}_{\mathrm{w} \text { initial }}$ & $0.96 \pm 0.00$ & $0.96 \pm 0.01$ & NS \\
\hline$a_{w} 48 h^{z}$ & $0.86 \pm 0.01$ & $0.86 \pm 0.01$ & NS \\
\hline$\%$ protein & $23.93 \pm 1.80$ & $23.99 \pm 1.67$ & NS \\
\hline$\%$ moisture & $44.49 \pm 0.70$ & $50.95 \pm 1.09$ & $* * *$ \\
\hline$\%$ ash & $1.01 \pm 0.20$ & $0.64 \pm 0.28$ & NS \\
\hline TBARS $^{\mathbf{y}}$ & $2.16 \pm 0.23$ & $1.87 \pm 0.33$ & NS \\
\hline
\end{tabular}

\footnotetext{
${ }^{\mathrm{z}}$ Air drying.

${ }^{\mathbf{y}} \mathrm{mg}$ MA eq. $\mathrm{kg}^{-1}$ sample.

$* *, * * * P<0.01$ and $P<0.001$, respectively; NS, not significant $(P>0.05)$.
} 
Significant differences between mantas were found in the IMF content $(P<0.001)$ and fatty acid profile in the LD (Table 2). Ewe mantas had a considerably higher $(P<0.001)$ IMF content than goat mantas, 14.89 and

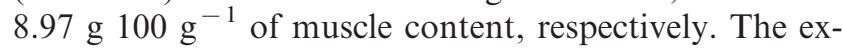
tensive fat content of ewe mantas was as saturated fatty acids (SFA), while in goats it was verified as monounsaturated fatty acid (MUFA), taking into account that ewe mantas had higher MUFA content $(P<0.001)$. The differences in fat content and fat partition found between these two sheep and goat processed meat products have also been recorded in fresh meat.

The most important saturated fatty acids in both mantas were C16 (palmitic), C18:0 (stearic) and the contents of these fatty acids were significantly higher in ewe than in goat mantas. The saturated fat in ewe and goat mantas, particularly the greater presence of $\mathrm{C} 16$ and $\mathrm{C} 18$, was similar to the values found by Facco (2009) for charque, but less than the quantities recorded in charque and jerked beef by Correia et al. (2003).

The most abundant unsaturated fatty acids were the C 18:1, the C 18:2 and the ratios UFA/SFA MUFA/ SFA PUFA/SFA although favorable to health in both products were higher in goat mantas. This confirms the tendency reported by Pearce et al. (2010) for goats to deposit a healthier fatty acid composition, and the studies by Lee et al. (2008), who observed higher levels of unsaturated fat in the meat of goats compared with lambs fed the same diet.

Table 2. Fatty acid profile (g $100 \mathrm{~g}^{-1}$ of longissimus dorsi muscle and total percentage of the three fats) of ewe and goat mantas (mean \pm SD)

\begin{tabular}{lccc}
\hline$N=48$ & \multicolumn{1}{c}{ Ewe } & \multicolumn{1}{c}{ Goat } & Significance \\
\hline Saturated & & & \\
$\mathrm{C}_{4}$ & $0.03 \pm 0.02(0.25)$ & $0.06 \pm 0.02(0.64)$ & $\mathrm{NS}$ \\
$\mathrm{C}_{8}$ & $0.13 \pm 0.01(0.98)$ & $0.14 \pm 0.01(1.75)$ & $\mathrm{NS}$ \\
$\mathrm{C}_{10}$ & $0.06 \pm 0.02(0.46)$ & $0.06 \pm 0.02(0.7)$ & $\mathrm{NS}$ \\
$\mathrm{C}_{12}$ & $0.05 \pm 0.01(0.37)$ & $0.05 \pm 0.03(0.6)$ & $\mathrm{NS}$ \\
$\mathrm{C}_{14}$ & $0.51 \pm 0.04(3.69)$ & $0.43 \pm 0.05(4.83)$ & $\mathrm{NS}$ \\
$\mathrm{C}_{16}$ & $2.89 \pm 0.21(19.34)$ & $1.80 \pm 0.30(19.51)$ & $* *$ \\
$\mathrm{C}_{18}$ & $2.49 \pm 0.19(16.22)$ & $1.02 \pm 0.27(11.15)$ & $* * *$ \\
Unsaturated & & & \\
$\mathrm{C}_{16: 1}$ & $0.39 \pm 0.04(2.66)$ & $0.39 \pm 0.06(4.14)$ & $\mathrm{NS}$ \\
$\mathrm{C}_{18: 1}$ & $5.46 \pm 0.40(36.53)$ & $3.21 \pm 0.56(34.74)$ & $* * *$ \\
$\mathrm{C}_{18: 2}$ & $0.87 \pm 0.06(5.82)$ & $0.44 \pm 0.09(5.07)$ & $* * *$ \\
$\mathrm{C}_{18: 3}$ & $0.17 \pm 0.02(1)$ & $0.03 \pm 0.03(0.26)$ & $*$ \\
$\mathrm{C}_{20: 4}$ & $0.02 \pm 0.01(0.15)$ & $0.04 \pm 0.01(0.61)$ & $\mathrm{NS}$ \\
IM Fat & $14.89 \pm 1.02$ & $8.97 \pm 1.45$ & $* * *$ \\
$\Sigma$ SFA & $6.17 \pm 0.39(41.34)$ & $2.53 \pm 0.55(28.43)$ & $* * *$ \\
$\Sigma$ MUFA & $5.85 \pm 0.43(39.20)$ & $3.60 \pm 0.61(38.88)$ & $* * *$ \\
$\Sigma$ PUFA & $1.05 \pm 0.08(6.96)$ & $0.52 \pm 0.11(5.93)$ & $* * *$ \\
UFA/SFA $^{\mathrm{z}}$ & $1.12 \pm 0.08$ & $1.60 \pm 0.19$ & $* * *$ \\
MUFA/SFA & $0.95 \pm 0.07$ & $1.38 \pm 0.18$ & $* * *$ \\
PUFA/SFA & $0.17 \pm 0.02$ & $0.21 \pm 0.04$ & $* * *$ \\
\hline
\end{tabular}

${ }^{\mathrm{z}}$ SFA, saturated fatty acids; MUFA, monounsaturated fatty acids; PUFA, polyunsaturated fatty acids.

$*, * *, * * * P<0.05, P<0.01$, and $P<0.001$, respectively; NS, not significant $(P>0.05)$.
Our results show that both processed meats designated as ewe and goat mantas have high protein content, a balanced fat content and a resistance to oxidative processes, indicating that this process could be a strategy to differentiate meat from animals with very low commercial value. More research is required to assess the food safety, sensorial quality and commercial acceptance of these processed products.

Association of Official Analytical Chemists. 1997. Determination of total fat in foods and feeds by the Caviezel method, based on a gas chromotographic technique. Peer-Verified Method - PVM 4. AOAC, Gaithersburg, MD.

Babiker, S. A., El Khider, I. A. and Shafie, S. A. 2003. Chemical composition and quality attributes of goat meat and lamb. Meat Sci. 28: 273-277.

Correia, R. T. P. and Biscontini, T. M. B. 2003. Influência da dessalga e cozimento sobre a composição química e perfil de ácidos graxos de charque e jerked beef. Ciência e Tecnologia de Alimentos 23: 38-42.

Costa, R. G., Medeiros, G. R., Duarte, T. F., Pedrosa, N. A., Voltolini, T. V. and Madruga, M. S. 2011. Salted goat and lamb meat: Typical regional product of the city of Petrolina, state of Pernambuco. Small Rum. Res. 98: 51-54.

Cristian, H. M. P. G. 2006. Jerked beef fermentado. Desenvolvimento de nova tecnologia de processamento. Universidade Estadual de Londrina. pp. 70-72.

Facco, E. M. P., Lage, M. E. and Godoy, H. T. 2009. Influence of vitamin E supplemented diet on charque quality and lipid stabilization. Braz. Arch. Biol. Technol. 52: 729-736.

Fratianni, F., Sada, A., Orlando, P. and Nazzaro, F. 2008. Micro-electrophoretic study of sarcoplasmic fraction in the dry-cured goat raw ham. Open Food Sci. J. 2: 89-94.

Hierro, E., de la Hoza, L., Juan, A. and Ordóñez, J. A. 2004. Headspace volatile compounds from salted and occasionally smoked dried meats (cecinas) as affected by animal species. Food Chem. 85: 649-657.

Lee, J. H., Kannan, G., Eega, K. R., Kouakou, B. and Getz, W. R. 2008. Nutritional and quality characteristics of meat from goat and lamb finished under identical dietary regime. Small Rum. Res. 74: 255-259.

Madruga, M. S., Torres, T. S., Carvalho, F. F., Queiroga, R. C., Narain, N., Garrutti, D., Souza Neto, M. A., Mattos, C. W. and Costa, R. G. 2008. Meat quality of Moxotó and Canindé goats as affected by two levels of feeding. Meat Sci. 80: 1019-1023.

Madruga, M. S. and Bressan, M. C. 2011. Goat meats: Description, rational use, certification, processing and technological developments. Small Rum. Res. 98: 39-45.

NP-1612. 1979. Carnes, derivados e produtos cárneos. Determinação do teor de azoto total. Método de referência. IPQ, Lisbon, Portugal.

NP-1614. 2002. Carnes, derivados e produtos cárneos. Determinação da humidade. Processo de referência. IPQ, Lisbon, Portugal.

NP-1615. 2002. Carnes, derivados e produtos cárneos. Determinação da cinza total. Processo de referência. IPQ, Lisbon, Portugal.

Pearce, K. L., Norman, H. C. and Hopkings, D. L. 2010. The role of saltbush-based pasture systems for the production of high quality sheep and goat meat. Small Rum. Res. 91: 29-38. 
Rubio, B., Martínez, B., González-Fernández, C., García-Cachán, M. D., Rovira, J. and Jaime, I. 2007. Effect of modified atmosphere packaging on the microbiological and sensory quality on fry cured beef product: "Cecina de león". Meat Sci. 75: 515-522

Sobrinho, S. A. G., Zeola, N. M. B. L., Souza, H. B. A. and Lima, T. M. A. 2004. Qualidade da carne ovina submetida ao processo de salga. Ciência e Tecnologia de Alimentos 24: 369-372.

Teixeira, A. and Rodrigues, S. 2013. Pork meat quality of Preto Alentejano and Commercial Large White Landrace cross. J. Integr. Agric. 12: 1962-1971.
Teixeira, A., Pereira, E. and Rodrigues, S. 2011. Goat meat quality. Effects of salting, air-drying and ageing processes. Small Rum. Res. 98: 55-58.

Teixeira, A., Rodrigues, M., Pereira, E. and Rodrigues, S. 2010. The quality of a new sheep meat product. Effect of salting and ageing process. Book of Abstracts EAAP, No. 16: 125.

Webb, E. C., Casey, N. H. and Simela, L. 2005. Goat meat quality. Small Rum. Res. 60: 153-166. 